\title{
Pengembangan Media Pembelajaran Interaktif dengan Menggunakan Metode Multimedia Development Life Cycle
}

\author{
Mustika $^{1}$, Eka Prasetya Adhy Sugara ${ }^{2}$, Maissy Pratiwi ${ }^{3}$ \\ ${ }^{1}$ Jurusan Manajemen Informatika, Politeknik Palcomtech Palembang \\ ${ }^{2}$ Prodi Desain Komunikasi Visual, Politeknik Palcomtech Palembang \\ ${ }^{3}$ Jurusan Sistem Informasi, STMIK Palcomtech Palembang \\ ${ }^{1}$ mustika@palcomtech.ac.id, ${ }^{2}$ eka_p@palcomtech.ac.id, ${ }^{3}$ maissy.ptw@gmail.com
}

\begin{abstract}
Learning media used in IT Project Management course, sub subject Project Management Methodology at Sekolah Tinggi Manajemen dan Ilmu Komputer (STMIK) PalComTech Palembang still uses modules obtained from worksheets and lecturers use lecture methods in explaining the related subject. The lecture method still has weaknesses so that the development of instructional media is needed. This research uses six stages of Multimedia Development Life Cycle (MDLC) method, which is Concept, Design, Material Collecting, Assembly, Testing and Distribution. The purpose of this research is to create interactive learning media of project management course, sub subject about project management methodology consisting of initiation, planning, implementation, supervision and closing stages and also documents required in IT project management development. The benefit expected is that this learning media can be a tool in the lecturing process of IT Project Management in STMIK Palcomtech. Applications have been tested through blackbox testing, with the results all indicator of testing declared valid.
\end{abstract}

Keywords-blackbox testing, interactive learning media, multimedia

Abstrak- Media Pembelajaran memiliki peranan yang sangat penting pada proses perkuliahan. Media Pembelajaran yang digunakan pada mata kuliah Manajemen Proyek IT sub materi Metodologi Manajemen Proyek pada Sekolah Tinggi Manajemen Informatika dan Komputer (STMIK) PalComTech Palembang masih menggunakan modul yang didapat dari worksheet, dosen menggunakan metode ceramah dalam menjelaskan materi metodologi manajemen proyek. Metode ceramah masih memiliki kelemahan sehingga diperlukan pengembangan media pembelajaran. Penelitian ini mengunakan metode Multimedia Development Life Cycle (MDLC) dengan enam tahapan yaitu: konsep (Concept), perancangan (Desain), pengumpulan bahan(Material Collecting), pembuatan (Assembly), pengujian(Testing), dan distribusi (Distribution). Tujuan penelitian yaitu membuat media pembelajaran interaktif mata kuliah manajemen proyek, sub materi metodologi Manajemen Proyek yang berisikan tentang tahapan inisiasi, perencanaan, pelaksanaan, pengawasan dan penutupan, serta dokumen-dokumen yang diperlukan dalam pembangunan proyek IT. Manfaat yang diharapkan adalah media pembelajaran ini dapat menjadi alat bantu dalam proses perkuliahan manajemen proyek yang ada di STMIK Palcomtech. Aplikasi sudah diuji melalui blackbox testing, dengan hasil pengujian semua indikator dinyatakan baik.

Kata kunci- blackbox testing, media pembelajaran interaktif, multimedia

\section{PENDAHULUAN}

Media Pembelajaran memiliki peranan yang sangat penting pada proses perkuliahan. Penyajian media pembelajaran beraneka ragam, berupa grafik, film, slide, foto, serta pembelajaran dengan menggunakan komputer. Dalam media pembelajaran penggunaan media komputer berperan penting dalam menyalurkan, menyimpan dan memproses informasi, dimana proses belajar-mengajar menjadi komunikatif, efektif dan efisien.

Salah satu mata kuliah yang terdapat di STMIK Palcomtech yaitu mata kuliah manajemen proyek IT, yang memiliki sub pembahasan mengenai metodologi Manajemen Proyek (Project Management Methodology) seringkali disebut dengan istilah Tahapan Pengembangan Proyek (Project Development Stage). Metode pengajaran yang dilakukan dosen adalah dengan model ceramah.

Kelemahan model ceramah adalah a) Metode ceramah tidak dapat memberikan kesempatan untuk berdiskusi memecahkan masalah sehingga proses penyerapan pengetahuan kurang. b). Metode ceramah kurang memberi kesempatan kepada para siswa untuk mengembangkan keberanian mengemukakan pendapatnya. c). Pertanyaan lisan dalam ceramah kurang dapat ditangkap oleh indera pendengar. d). Metode ceramah kurang cocok dengan tingkah laku kemampuan anak yang masih kecil[1].

Melihat kelemahan model ceramah yang saat ini dilakukan, maka perlu diadakan pengembangan media pembelajaran. Salah satu bentuk model pembelajaran yang dapat dikembangkan adalah mengubah model ceramah menjadi model pembelajaran multimedia interaktif.

Rob Philips dalam Ali [2] menjelaskan makna interaktif sebagai suatu proses pemberdayaan siswa untuk mengendalikan lingkungan belajar. Dalam konteks ini lingkungan belajar yang dimaksud adalah belajar dengan 
menggunakan komputer. Klasifikasi interaktif dalam lingkup multimedia pembelajaran bukan terletak pada sistem hardware, tetapi lebih mengacu pada karakteristik belajar siswa dalam merespon stimulus yang ditampilkan layar monitor komputer. Kualitas interaksi siswa dengan komputer sangat ditentukan oleh kecanggihan program komputer. Media pembelajaran interaktif dipandang perlu, mengingat kelebihan dari media pembelajaran interaktif dapat berinteraksi secara lebih luas. Pembelajaran pun menjadi lebih bersifat pribadi yang akan memenuhi kebutuhan strategi pembelajaran yang berbeda-beda.

Penelitian mengenai media pembelajaran interaktif pernah dilakukan oleh Fikriyaturrohmah, dkk [3] hasil penelitiannya adalah produk media pembelajaran interaktif Hands-On Equations pada materi persamaan linier satu variabel untuk siswa kelas VII SMP. Pengembangan media ini menggunakan metode pengembangan Sadima, Media pembelajaran yang dihasilkan secara keseluruhan merupakan media yang berkualitas karena memenuhi kriteria valid dan praktis.

Ongkohardjo, dkk [4] melakukan penelitian untuk menghasilkan media pembelajaran yang mengemas pelajaran gaya dan tekanan pada fisika untuk anak SMP menjadi lebih interaktif dan menarik, dimana pemain terlibat aktif dalam proses pembelajaran. Mulai dari materi hukum newton, berbagai macam gaya, dan tekanan pada suatu zat (padat, cair, dan gas). Tersedia juga simulasi-simulasi pendukung untuk memudahkan pemain dalam pemahaman materi. Aplikasi ini dibuat menggunakan Adobe Flash Professional CS6. Dari hasil kuisioner, membuktikan bahwa simulasi dalam aplikasi sangat mendukung dalam proses pemahaman materi. Maka dari itu minat belajar pemain semakin bertambah, ditambah dengan penggunaan aplikasi yang sangat mudah.

Pengembangan media pembelajaran interaktif membutuhkan metode pengembangan perangkat lunak, salah satu metode pengembangan yang dapat digunakan adalah metode Multimedia Development Life Cycle $(M D L C)$. Nurajizah [5] pernah menggunakan metode MDLC dalam mengembangkan aplikasi pengenalan lagu anak-anak berbasis multimedia, proses pembuatan aplikasi menggunakan enam tahapan yaitu: konsep (Concept), perancangan (Desain), pengumpulan bahan (Material Collecting), pembuatan (Assembly), pengujian (Testing), dan distribusi (Distribution).

Berdasarkan penjelasan sebelumnya, maka penelitian ini akan mengunakan metode MDLC dalam mengembangkan media pembelajaran interaktif pada mata kuliah manajemen proyek dalam ruang lingkup materi ajar metodologi Manajemen Proyek.

Tujuan penelitian adalah membuat media pembelajaran interaktif mata kuliah manajemen proyek, sub materi metodologi Manajemen Proyek dengan menggunakan metode MDLC. Manfaat yang diharapkan adalah media pembelajaran ini dapat menjadi alat bantu dalam proses perkuliahan manajemen proyek yang ada di STMIK Palcomtech.

\section{METODE PENELITIAN}

Pengembangan metode multimedia ini dilakukan berdasarkan enam tahap, yaitu concept (pengonsepan), design (perancangan), material collecting (pengumpulan bahan), assembly (pembuatan), testing (pengujian), dan distribution (pendistribusian). Menurut Luther dalam Binanto [6], keenam tahap ini tidak harus berurutan dalam praktiknya, tahap-tahap tersebut dapat saling bertukar posisi. Meskipun begitu, tahap concept memang harus menjadi hal yang pertama kali dikerjakan. Gambar 1 adalah gambar tahapan metode MDLC.

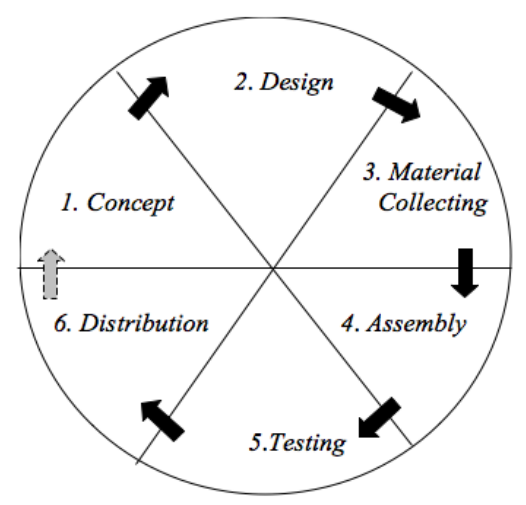

Gambar 1. Tahapan metode MDLC

\section{Concept (Pengonsepan)}

Tahap ini adalah tahap untuk menentukan tujuan dan siapa pengguna program (identifikasi audiens). Tujuan dan penggunaan akhir program berpengaruh pada nuansa multimedia sebagai pencerminan dari identitas organisasi yang menginginkan informasi sampai pada pengguna akhir. Pada tahap ini, peneliti melakukan pengonsepan antara lain untuk:

a. Menentukan tujuan dan manfaat aplikasi media pembelajaran metodologi manajemen proyek.

b. Menentukan siapa saja penguna aplikasi media pembelajaran metodologi manajemen proyek

c. Mendeskripsikan konsep aplikasi Media Pembelajaran Interaktif Manajemen Proyek IT yang akan dibangun.

\section{Design (Perancangan)}

Pada tahap ini pembuatan spesifikasi mengenai arsitektur program, gaya, tampilan, dan kebutuhan material / bahan untuk program. Desain yang akan dibuat mengunakan desain interface dari tampilan menu aplikasi. Perangkat lunak yang digunakan untuk merancang interface adalah Microsoft Visio.

\section{Material Collecting (Pengumpulan Bahan)}


Tahap ini adalah tahap pengumpulan bahan yang sesuai dengan kebutuhan yang dikerjakan. Bahan-bahan tersebut antara lain gambar clip art, foto, animasi, video, audio, dan lain-lain yang dapat diperoleh secara gratis atau dengan pemesanan kepada pihak lain sesuai dengan rancangannya. Tahap ini dapat dikerjakan secara parallel dengan tahap assembly. Namun, pada beberapa kasus, tahap material collecting dan tahap assembly akan dikerjakan secara linear dan tidak parallel.

\section{Assembly (Pembuatan)}

Tahap assembly (pembuatan) adalah tahap pembuatan semua objek atau bahan multimedia. Pembuatan aplikasi didasarkan pada tahap desain, seperti storyboard, bagan alir, dan/atau struktur navigasi.

\section{Testing (Pengujian)}

Tahap testing (pengujian) dilakukan setelah menyelesaikan tahap pembuatan (assembly) dengan menjalankan aplikasi / program dan dilihat apakah ada kesalahan atau tidak. Tahap pertama pada tahap ini disebut juga sebagai tahap pengujian alpha (alpha test) yang pengujiannya dilakukan oleh pembuat atau lingkungan pembuatnya sendiri. Setelah lolos dari pengujian alpha, pengujian beta yang melibatkan penggunaan akhir akan dilakukan.

\section{Distribution(Pendistribusian)}

Tahap ini aplikasi akan disimpan dalam suatu media penyimpanan. Jika media penyimpanan tidak cukup untuk menampung aplikasinya, kompresi terhadap aplikasinya, kompresi terhadap aplikasi tersebut akan dilakukan. Tahap ini juga dapat disebut tahap evaluasi untuk pengembangan produk yang sudah jadi supaya menjadi lebih baik.

Gambar 2 adalah gambar alur media pembelajaran yang akan dibangun. Alur menggambarkan dari tahap awal sampai akhir alur.

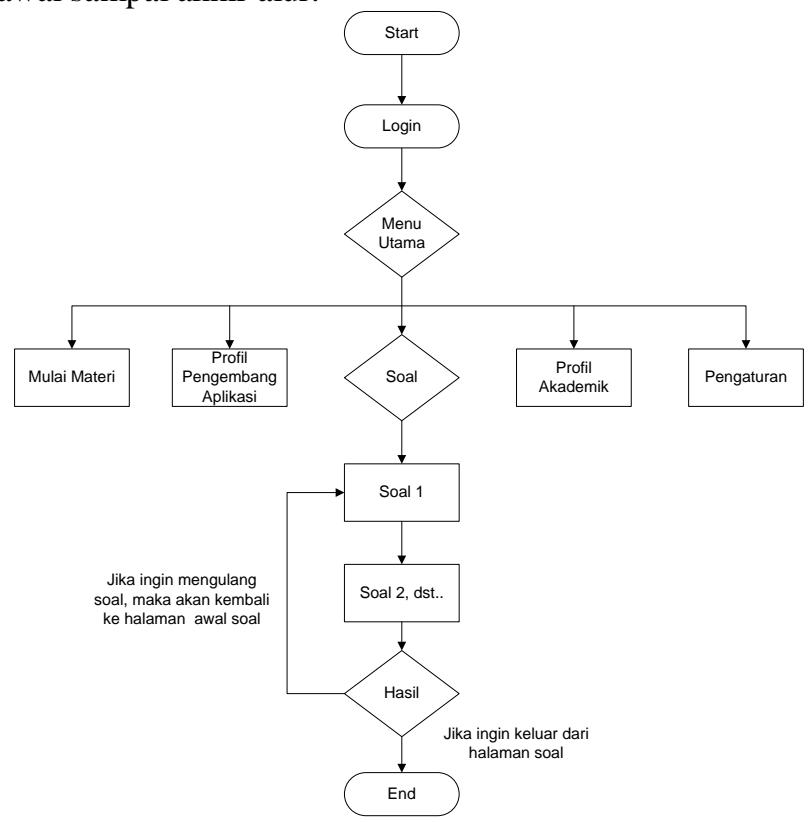

Gambar 2. Alur Media Pembelajaran

III. HASIL DAN PEMBAHASAN

Penggunaan metode MDLC menghasilkan hasil penelitian dengan langkah sebagai berikut:

1. Concept (Pengonsepan)

Tahapan ini menghasilkan rumusan konsep yaitu:

a. Tujuan aplikasi yaitu sebuah media pembelajaran interaktif berbasis multimedia mata kuliah manajemen proyek IT untuk sub materi metodologi manajemen proyek. Manfaat aplikasi untuk mempermudah pembelajaran materi Metodologi Manajemen Proyek, agar mahasiswa dapat lebih termotivasi untuk belajar.

b. Pengguna aplikasi adalah dosen dan juga mahasiswa STMIK PalComTech Palembang.

c. Deskripsi Aplikasi Media Pembelajaran Interaktif Manajemen Proyek IT, berbasis multimedia. Aplikasi dapat dioperasikan pada perangkat komputer.

\section{Design (Perancangan)}

Dalam tahapan ini, perancangan yang dibuat menggunakan metode desain interface menu aplikasi media pembelajaran manajemen proyek. Tidak menggunakan desain storyboard dikarenakan media tidak memiliki alur cerita, melainkan alur proses. Hasil desain yang dilakukan dengan menggunakan Microsoft Visio 2017 sebagai berikut:

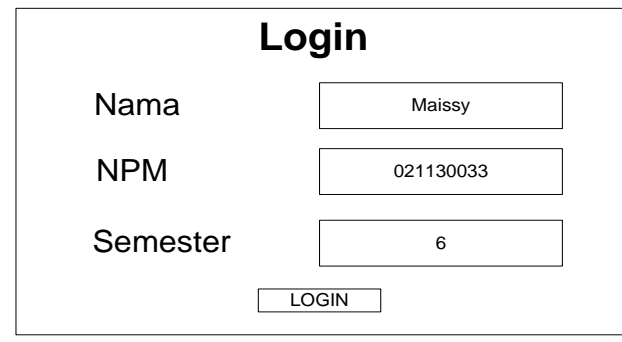

Gambar 3. Desain halaman login

Gambar 3 adalah desain halaman login. Alur akan dimulai dengan mengisi Nama, NPM, dan Semester, lalu menekan tombol login maka akan tampil menu utama. Data yang dimasukkan saat proses login harus lengkap, jika terdapat salah satu data yang tidak diisi, maka akan tampil halaman login gagal.

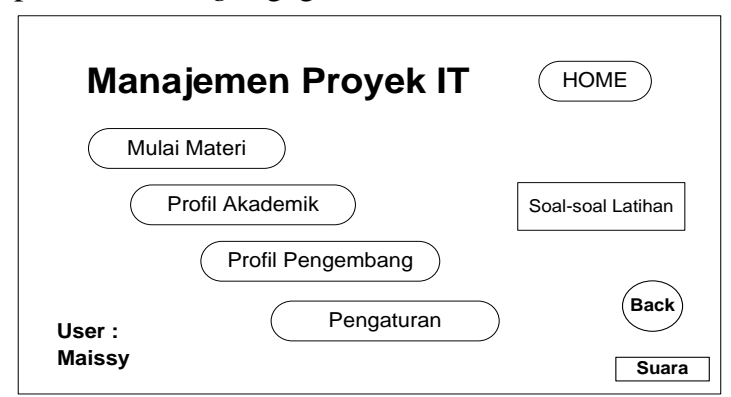

Gambar 4. Desain halaman utama 
Gambar 4 adalah desain halaman utama. Halaman ini akan digunakan untuk mengendalikan semua kegiatan halaman. Dalam halaman ini terdapat tombol home, mulai materi, profil akademik, profil pengembang, pengaturan, soal-soal latihan, back, dan suara. Jika tombol-tombol tersebut diklik maka akan muncul tampilan baru yang isinya berbeda-beda sesuai nama dari tombol yang diklik.
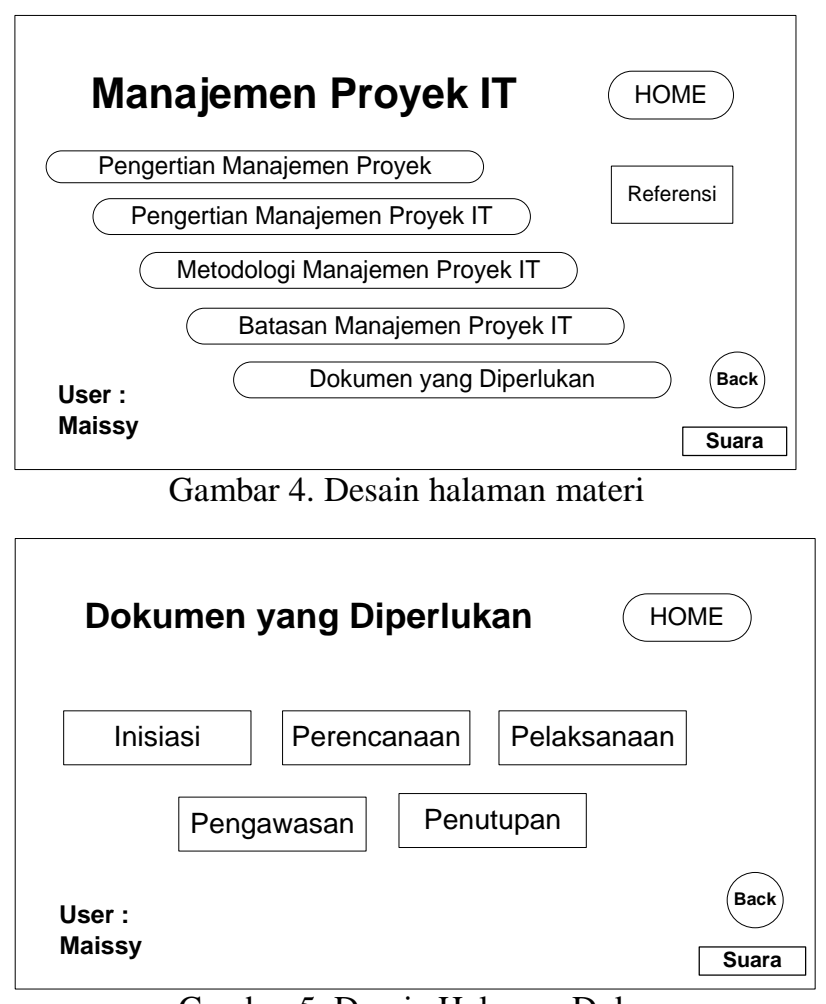

Gambar 5. Desain Halaman Dokumen

Gambar 5 adalah halaman yang akan menampilkan tombol tahap inisiasi, perencanaan, pelaksanaan, pengawasan, penutupan, dan tombol home, back, suara serta nama user. Jika tombol tahap inisiasi diklik, maka akan beralih ke halaman contoh dokumen tahap inisiasi. Jika tombol tahap perencanaan diklik, maka akan beralih ke halaman contoh dokumen tahap perencanaan. Jika tombol tahap pelaksanaan diklik, maka akan beralih ke halaman contoh dokumen tahap pelaksanaan. Jika tombol tahap pengawasan diklik, maka akan beralih ke halaman contoh dokumen tahap pengawasan. Jika tombol tahap penutupan diklik, maka akan beralih ke halaman contoh dokumen tahap penutupan.

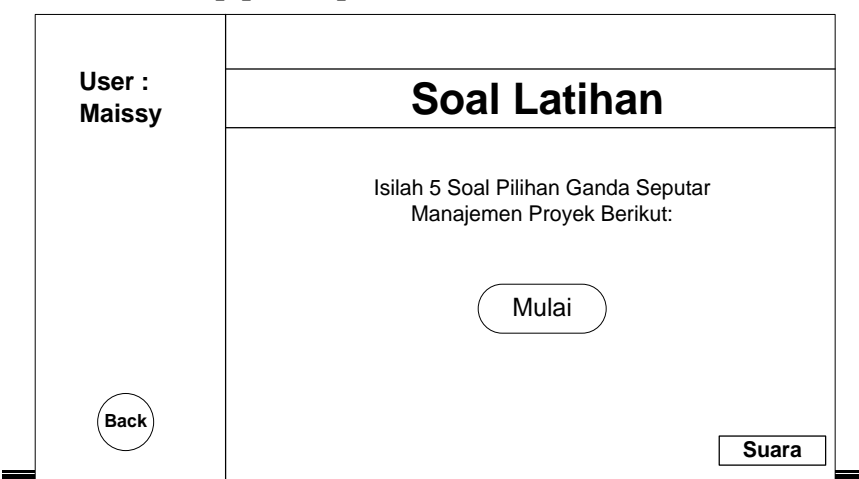

Gambar 6. Desain Halaman Soal

Gambar 6 adalah desain Halaman Soal, halaman ini yang akan menampilkan soal-soal latihan tentang materi yang terkait dalam media pembelajaran tersebut, terdapat tombol mulai, back, dan suara, serta terdapat judul "Soal Latihan" dan kalimat "Isilah 5 Soal Pilihan Ganda Seputar Manajemen Proyek Berikut". Pada saat tombol mulai diklik maka akan menampilkan soal, terdapat 5 soal pilihan ganda, pada soal tersebut menggunakan timer selama 3 menit, cara menjawab soal tersebut dengan cara mengklik jawaban yang dianggap benar, jika soal telah selesai diisi secara otomatis nilai akan tampil, dan jika waktu telah habis maka akan tampil nilai yang telah diisi. Pada saat mengisi soal, tombol back tidak tampil agar user tidak dapat keluar dari halaman soal saat soal belum selesai diisi, setelah soal selesai diisi dan menampilkan nilai,maka tombol back kembali ke halaman soal. Jika ingin mengulang soal, maka soal akan kembali ke nomor awal dengan soal yang telah diacak. Jika tidak, maka akan keluar dari halaman soal.

\section{Material Collecting (Pengumpulan Bahan)}

Pada tahapan ini, materi terkait bahan ajar/materi pembelajaran didapatkan dari wawancara kepada dosen yang mengampuh mata kuliah Manajemen Proyek, membaca buku dan mencari sumber-sumber lainnya dari internet. Sedangkan untuk materi terkait multimedia interaktif, penulis mendapatkan materi dari buku referensi, dan internet. Bahan pembuatan aplikasi yang dikumpulkan adalah image atau gambar seperti gambar yang akan digunakan sebagai background maupun dokumen dalam manajamen proyek, suara yang akan digunakan sebagai intro.

Untuk membangun aplikasi maka dibutuhkan perangkat keras dan lunak. Perangkat keras yang digunakan adalah seperangkat komputer dengan spesifikasi: Processor Intel Inside Core i5, Memory 6 GB dan Monitor 14.0". Untuk perangkat lunak yang dibutuhkanlah adalah Windows 7 Home Premium sebagai Sistem Operasi dan Adobe Flash Professional CS3 digunakan untuk membuat dan mengolah aplikasi.

\section{Assembly (Pembuatan)}

Pada tahapan ini, pembuatan aplikasi menggunakan Software Adobe Flash Professional CS3, untuk desain menggunakan SoftwareAdobe Photoshop CS3. Proses pembuatan aplikasi manajemen proyek IT berdasarkan proses desain sebagai berikut :

\section{a. Tampilan Halaman Login}

Gambar 7 adalah tampilan halaman login ini berupa background dengan kotak persegi yang berisi Nama, NPM dan Semester, lalu dilengkapi dengan text box untuk mengisi data user yang sedang menggunakan aplikasi. Serta terdapat judul "Login" dan dilengkapi gambar dua 
orang karyawan. Terdapat tombol login dan exit pada halaman login.

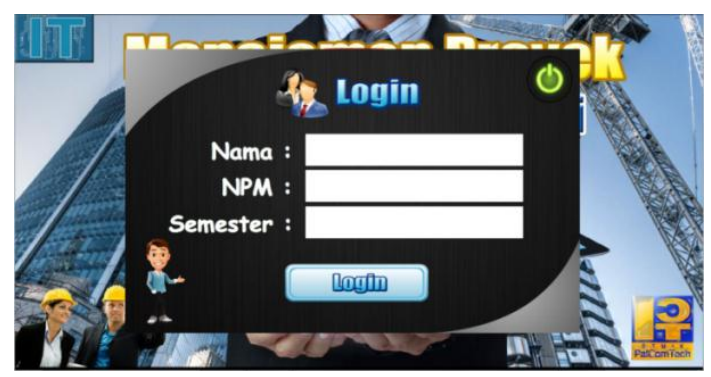

Gambar 7. Tampilan Halaman Login

\section{b. Tampilan Halaman Utama}

Gambar 8 adalah tampilan halaman utama ini menampilkan tombol mulai materi, profil akademik, profil pengembang, pengaturan, soal-soal latihan, tombol home, volume, serta nama user.

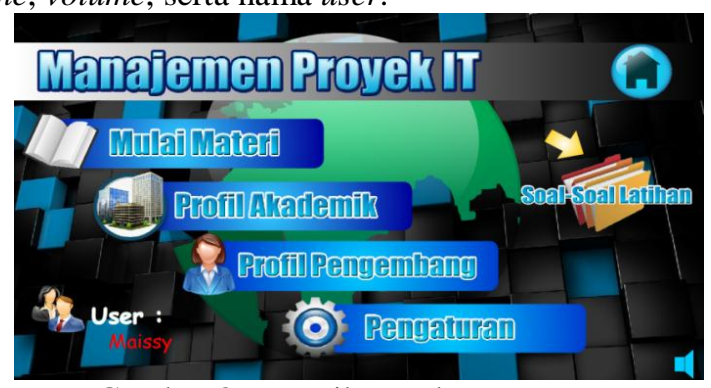

Gambar 8. Tampilan Halaman Utama

Gambar 8 adalah halaman utama dimulai dengan animasi bola dunia berputar, animasi tersebut mengkombinasikan warna hijau dan putih transparan, terdapat animasi persegi panjang yang bergerak secara horizontal dengan warna gradient putih dan hitam yang dilanjutkan dengan animasi judul "Manajemen Proyek IT" yang memiliki warna gradient biru dan putih dengan efekstroke berwarna biru tua (dark blue), serta animasi tombol home dengan warna biru dan simbol rumah berwarna hitam. Dilanjutkan dengan animasi tombol mulai materi dengan gambar vektor buku, dan dilanjutkan juga animasi tombol profil akademik dengan gambar vektor gedung, animasi tombol profil pengembang dengan gambar vektor mahasiswa, dan animasi tombol pengaturan dengan gambar vektor simbol pengaturan, semua tombol tersebut mengkombinasikan warna gradient biru tua dan biru muda, animasi tombol tersebut bergerak dari arah kanan ke kiri. Setelah itu, akan tampil tombol soal-soal latihan dan tombol suara. Tombol soalsoal latihan dilengkapi dengan gambar vektor dokumendan disertai dengan simbol panah yang begerak keatas dan kebawah secara berulang, simbol panah tersebut berwarna gradient kuning dan putih menggunakan jenis huruf Impact dengan warna gradient biru tua dan biru muda dengan efek stroke berwarna putih,serta tombol suara berwarna biru.

Pengembangan Media Pembelajaran Interaktif Dengan Menggunal Multimedia Development Life Cycle

(Mustika, Eka Prasetya Adhy Sugara, Maissy Pratiwi) c. Tampilan Halaman Dokumen yang diperlukan

Pada halaman ini terdapat suara pembuka yang berbunyi "Dokumen yang Diperlukan" dengan menampilkan menampilkan background yang sama pada halaman utama dengan animasi persegi panjang berwarna gradient putih dan hitam yang bergerak horizontal, dilengkapi dengan judul "Dokumen yang Diperlukan" yang memiliki warna gradient biru dan putih dengan efek stroke berwarna putih, dan terdapat tombol home berwarna gradient biru dan putih, serta simbol rumah yang memiliki warna hitam, serta terdapat tombol back dan suara, serta menampilkan nama user.

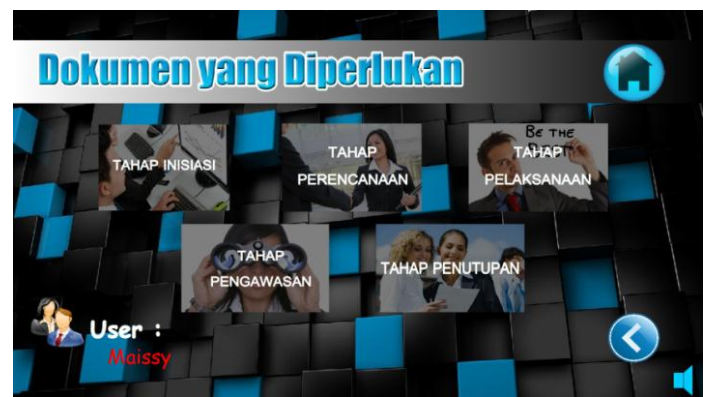

Gambar 9. Tampilan Halaman Dokumen yang Diperlukan

Gambar 9 adalah Tampilan Halaman Dokumen yang Diperlukan. Pada halaman ini terdapat tombol tahap inisiasi, tahap perencanaan, tahap pelaksanaan, tahap pengawasan, dan tahap penutupan. Pada tombol tahap inisiasi terdapat gambar dua orang yang sedang bekerja menggunakan komputer. Pada tombol tahap perencanaan terdapat gambar dua orang yang sedang bersalaman. Pada tombol tahap pelaksanaan terdapat gambar seorang yang sedang menulis kalimat "Be The Best". Pada tombol tahap pengawasan terdapat gambar dua seorang yang sedang menggunakan teropong. Serta pada tombol tahap penutupan terdapat gambar dua orang yang sedang melihat dokumen, semua tombol tersebut menggunakan jenis huruf Browallia New dengan warna putih serta ukuran huruf "49".

\section{d. Tampilan Halaman Soal}

Gambar 10 adalah Tampilan Halaman Soal, pada halaman ini menggunakan background yang sama dengan halaman-halaman sebelumnya dilengkapi dengan kotak persegi berwarna biru transparan dengan opacity $54 \%$ dengan kalimat "Isilah 5 Soal Pilihan Ganda Seputar Manajemen Proyek Berikut", serta kotak persegi panjang dengan gradient warna biru dan hitam dengan judul "Soal Latihan", terdapat tombol mulai, back, dan suara serta terdapat nama user.

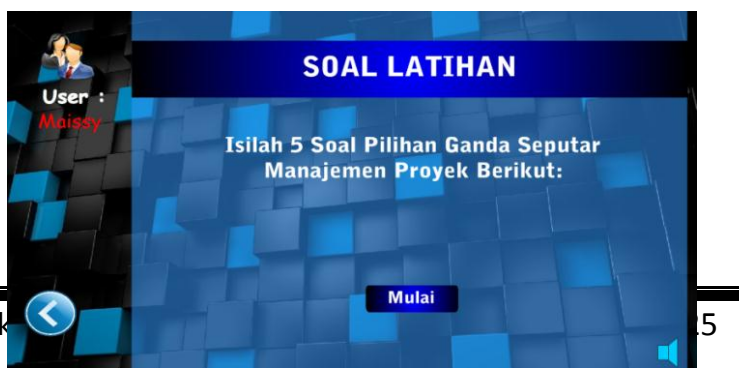




\section{Gambar 10. Tampilan Halaman Soal}

Pada halaman ini dimulai dengan suara yang berbunyi "Soal-soal Latihan" dan terdapat judul "Soal Latihan" dengan jenis huruf Bell Gothic Std Black dengan style bold dan huruf berwarna putih serta ukuran huruf "56". Terdapat kalimat pembuka "Isilah 5 Soal Pilihan Ganda Seputar Manajemen Proyek Berikut" dengan jenis huruf Bell Gothic Std Black dengan style Bold dan huruf berwarna putih serta ukuran huruf " 25 ", dan dilengkapi dengan tombol mulai dengan warna gradient biru tua dan hitam dengan jenis huruf Bell Gothic Std Black dengan Style Bold dan ukuran huruf " 25 ".

\section{Testing (Pengujian)}

Tahap testing dilakukan setelah selesai tahap assembly dengan menjalankan aplikasi/program dapat dilihat apakah ada kesalahan atau tidak. Pada tahap ini, dilakukan pengujian menggunakan blackbox testing. Metode blackbox ini merupakan pengujian program berdasarkan fungsi dari program. Tujuan dari metode blackbox testing ini adalah untuk menemukan kesalahan fungsi pada program. Pengujian blackbox berfokus pada persyaratan fungsional perangkat lunak. Pengujian ini memungkinkan analisis sistem memperoleh kondisi input yang mengerjakan seluruh keperluan fungsional aplikasi. Dari skenario pengujian terakhir yang dilakukan secara berulang-ulang dapat diperoleh hasil pengujian. Hasil pengujian dapat dilihat pada tabel 1 .

Tabel 1. Hasil Pengujian

\begin{tabular}{|c|c|c|c|}
\hline No. & & Kegiatan Testing & Hasil Pengujian \\
\hline \multirow[t]{3}{*}{1.} & $\begin{array}{l}\text { Image/ } \\
\text { Gambar }\end{array}$ & $\begin{array}{l}\text { Pengujian pada gambar } \\
\text { background aplikasi. }\end{array}$ & $\mathrm{Ok}$ \\
\hline & & $\begin{array}{l}\text { Pengujian gambar padabutton } \\
\text { aplikasi. }\end{array}$ & $\mathrm{Ok}$ \\
\hline & & $\begin{array}{l}\text { Pengujian padaImage pendukung } \\
\text { aplikasi. }\end{array}$ & $\mathrm{Ok}$ \\
\hline 2. & $\begin{array}{l}\text { Button/ } \\
\text { Tombol }\end{array}$ & $\begin{array}{l}\text { pengujian pada Button Materi } \\
\text { pengujian pada Button Soal } \\
\text { pengujian pada ButtonHome } \\
\text { pengujian pada Button Back } \\
\text { pengujian pada Button Exit }\end{array}$ & $\begin{array}{l}\text { Ok } \\
\text { Ok } \\
\text { Ok } \\
\text { Ok } \\
\text { Ok }\end{array}$ \\
\hline 3. & Animasi & pengujian pada animasiloading. & $\mathrm{Ok}$ \\
\hline 4. & Suara & $\begin{array}{l}\text { pengujian pada suara latar aplikasi. } \\
\text { pengujian suarapada button } \\
\text { aplikasi. }\end{array}$ & $\begin{array}{l}\mathrm{Ok} \\
\mathrm{Ok}\end{array}$ \\
\hline
\end{tabular}

\section{Distribution(Pendistribusian)}

Tahap distribution adalah tahap dimana aplikasi disimpan dalam suatu media penyimpanan. Seperti hardisk dan $\mathrm{CD}$ yang sebelumnya sudah dijadikan file autoplay. Ini merupakan tahap akhir dimana media (dalam bentuk CD) telah siap untuk dioperasikan maupun digandakan untuk dipublikasikan. Aplikasi media pembelajaran manajemen proyek IT ini dibuat menggunakan Adobe Flash Professional CS3 ActionScript 2.0, dimana file-file proyek disimpan dalam bentuk *.fla (flash CS3 document). Setelah aplikasi selesai dibuat, aplikasi di-export menjadi file *.exe, agar aplikasi tersebut dapat dijalankan dengan mudah di perangkat komputer.

\section{IV.PENUTUP}

Metode MDLC dapat digunakan dalam pengembangan media pembelajaran manajemen proyek IT. Penelitian ini menghasilkan media pembelajaran multimedia interaktif berupa aplikasi media pembelajaran Manajemen Proyek IT pada materi Metodologi Manajemen Proyek yang bertujuan untuk memudahkan proses belajar-mengajar antara dosen dan mahasiswa. Media pembelajaran Manajemen Proyek IT pada materi Metodologi Manajemen Proyek berisi penjelasan tentang tahapan inisiasi, perencanaan, pelaksanaan, pengawasan dan penutupan proyek, serta dokumen-dokumen yang diperlukan dalam pembangunan proyek IT. Media pembelajaran yang dibuat sudah diuji dengan teknik blackbox testing dengan hasil baik.

Saran untuk peneliti selanjutnya adalah dapat melakukan pengembangan media pembelajaran interaktif selanjutnya diharapkan dapat membuat media pembelajaran interaktif yang lebih menarik lagi, dengan mengkombinasikan animasi berbentuk 3D serta suara (dubbing). Menerapkan media pembelajaran dengan menggunakan model belajar dinamis (dynamic learning). Perlu penambahan materi sehingga aplikasi multimedia interaktif inidapat digunakan sepenuhnya pada Mata Kuliah Manajemen Proyek IT.

\section{REFERENSI}

[1] Sagala, S., Konsep dan Makna Pembelajaran. Bandung: Alfabeta. 2010.

[2] Ali, M., "Pengembangan Media Pembelajaran Interaktif mata kuliah medan elektromagnetik", Jurnal Edukasi@Elektro Vol.5, No.1, hal: 11-18, 2009.

[3] Fikriyaturrohmah., "Pengembangan Media Pembelajaran Interaktif Hands-On Equations Berbantu Komputer Pada Materi Persamaan Linear untuk siswa kelas VII". Jurnal online universitas negeri malang, Vol 1, No 3, 2012.

[4] Ongkohardjo, SA., Purba, KR., and Santoso, LW. "Pembuatan Media Pembelajaran Gaya dan Tekanan Fisika untuk Siswa SMP Berbasis Flash". Jurnal INFRA Vol. 4. No.2. hal: 1-5, 2016.

[5] Nurajizah, S., "Implementasi Multimedia Development Life Cycle Pada Aplikasi Pengenalan Lagu Anak-Anak Berbasis Multimedia". Jurnal PROSISKO Vol. 3 No. 2 hal: 14-19, 2016.

[6] Binanto, I.,. Multimedia Digital-Dasar Teori dan Pengembangannya. Yogyakarta: Andi, 2010 